J. Clin. Chem. Clin. Biochem.

Vol. 15,1977 , pp. $353-358$

\title{
Determination of Phenobarbital and Phenytoin in Serum by a Mechanized Enzyme Immunoassay (EMIT) in Comparison with a Gas-Liquid Chromatographic Method ${ }^{1}$ )
}

\author{
By M. Oellerich, W. R. Külpmann, R. Haeckel and R. Heyer
}

Technical Assistance: I. Isberner, F. Behrends and K. Petry

Institut für Klinische Chemie und Kinderklinik der Medizinischen Hochschule Hannover

(Received December 3, 1976/January 19, 1977)

\begin{abstract}
Summary: The antiepileptic drugs phenobarbital and phenytoin were determined in serum by enzyme immunoassay (Emit, Syva Corp.) and gas-liquid chromatography. The Emit assays were mechanized by the use of an Eppendorf analyzer 5010. The precision of the Emit system was sufficient (coefficient of variation within series 6-13\% and from day to day $8-15 \%$ with various calibrators and control sera). Moreover the Emit method is rapid, specific and easy to perform. The procedure requires only $10 \mu \mathrm{l}$ of serum per determination. A disadvantage however is the ligh cost of the reagents. A comparison of the results obtained by Emit and gas-liquid chromatography in a series of about 50 patients showed a good correlation between both methods (correlation coefficient $r=0.968$ for phenobarbital and 0.978 for phenytoin).
\end{abstract}

Bestimmung von Phenobarbital und Phenytoin im Serum mit einem mechanisierten Enzymimmuntest (Emit) im Vergleich zu einer gas-liquid chromatographischen Methode

Zusammenfassung: Die antiepileptischen Pharmaka Phenobarbital und Phenytoin wurden mit einem Enzymimmuntest (Emit, Syva Corp.) und einer gas-liquid chromatographischen Methode bestimmt. Die Emit Tests wurden durch Verwendung eines Eppendorf Enzymautomaten 5010 mechanisiert. Die Präzision des Emit Systems war ausreichend (Variationskoeffizient in der Serie 6-13\% und von Tag zu Tag 8-15\% mit verschiedenen Kalibratoren und Kontrollseren). Darüber hinaus ist das Emitverfahren schnell, spezifisch und leicht durchführbar. Für eine Bestimmung werden nur $10 \mu \mathrm{l}$ Serum benötigt. Nachteilig sind jedoch die hohen Kosten der Reagenzien. Ein Vergleich der Ergebnisse, welche mit Ëmit und Gas-Liquid-Chromatographie in einer Serie von etwa 50 Patienten erhalten wurden, zeigte eine gute Úbereinstimmung beider Methoden (Korrelationskoeffizient $r=0,968$ für Phenobarbital und 0,978 für Phenytoin).

\section{Introduction}

The efficiency and safety of the treatment of epileptic patients with anti-epileptic drugs has been considerably increased by monitoring the serum level of these drugs. The quantitative determination of serum antiepileptic drug levels facilitates individualization of dosage regimens, reveals irregular drug intake and identifies the responsible agent in intoxicated patients on multiple drug therapy $(1,2)$. Phenytoin $\left.{ }^{2}\right)$ and phenobarbital ${ }^{3}$ ) belong to the most commonly used drugs in the treatment of epilepsy. In the past few years many gas-liquid chromatographic methods for the determination of

\footnotetext{
1) Parts of this study have been reported at the 2nd European congress on Clinical Chemistry in Prague 1976.

2) 5,5-Diphenyl-imidazolidin-2,4 dion.

3) 5-Ethyl-5-phenyl-barbituric acid.
}

these compounds have been described. These techniques however, are rather time consuming. Recently homogeneous enzyme immunoassays for the quantitative measurement of phenobarbital and phenytoin have become commercially available, which are based on the "Enzyme Multiplied Immunoassay Technique" (Emit) (3). The Emit system has been demonstrated to be a reliable test for drugs of abuse in urine $(4,5)$. In contrast to other immunoassay techniques homogeneous enzyme immunoassays can easily be mechanized. The adaptation of the Emit System to the centrifugal analyzer has recently been reported $(6,7)$.

In the present study a rapid mechanized procedure for the quantitation of phenytoin and phenobarbital by Emit was evaluated using an Eppendorf analyzer 5010. The results obtained by this method are compared with those determined by gas-liquid chromatography. 


\section{Material and Methods}

Origin of specimens

Serum samples $(n=90)$ containing phenytoin and phenobarbital, a metabolite of primidone, were obtained from epileptic patients of our hospital. Control sera were purchased from Syva Corporation (AED, antiepileptic drug control) and from Laboratoires Biotrol in Paris (Biotrol-therapeutique).

\section{Materials}

The reagents for the enzyme immunoassay (Emit) were purchased from Syva Corp. (Palo Alto, California 94309). Substances tested for cross-reactivity were a generous gift of the manufacturers of the drugs mentioned by trade names.

\section{Gas-Liquid Chromatography}

The determination of phenobarbital and phenytoin by gasliquid chromatography was carried out according to a modified version of the procedure of Fiereck \& Tietz (8) without methylation (Külpmann, W. R. in preparation).

$2 \mathrm{ml}$ of saturated $\left(\mathrm{NH}_{4}\right)_{2} \mathrm{SO}_{4}$ solution is added to $1 \mathrm{ml}$ of the serum sample. The mixture is extracted 3 times with $5 \mathrm{ml}$ chloroform. The organic phase is dried over $\mathrm{Na}_{2} \mathrm{SO}_{4}$ and evaporated. The residue is washed down from the tube sides with 200 $\mu$ l ethyl acetate/acetic acid (volumes, $100 \mathrm{ml}+1 \mathrm{ml}$ ) and evaporated again. Then the dried residue is dissolved in $100 \mu \mathrm{l}$ of ethyl acetate/acetic acid (volumes, $100 \mathrm{ml}+1 \mathrm{ml}$ ); $2 \mu \mathrm{l}$ of this solution are injected into the gas chromatograph. A Varian model 1800 gas chromatograph (Varian, Darmstadt, FRG) equipped with a dual hydrogen flame detector is used. Glass columns are silanised $(180 \mathrm{~cm} \times 2.2 \mathrm{~mm}$, i. d.). They are packed with $3 \%$ SP 2250 DA on 100-120 mesh Chromosorb WHP (Supeloo, Bellefonte, Pennsylvania). Carrier gas flow rate is $40 \mathrm{ml} / \mathrm{min}$, hydrogen $30 \mathrm{ml} / \mathrm{min}$, and air $300 \mathrm{ml} / \mathrm{min}$. The column temperature is maintained at $230^{\circ} \mathrm{C}$, the inlet and the detector at $260^{\circ} \mathrm{C}$. The concentration of drugs is calculated by means of the slope of the regression line from the peak heights of the injected standard concentrations.

Enzyme immunoassay (Emit)

The original procedure of the Emit antiepileptic drug assays was adapted to the Eppendorf analyzer 5010 (Eppendorf, Hamburg, FRG).

Serum and reagent $A$, which contains the antibodies, the enzyme substrate glucose-6-phosphate and $\mathrm{NAD}^{+}$are preincubated for 15 minutes at $25^{\circ} \mathrm{C}$. Then the reaction is started with reagent $B$ containing glucose-6-phosphate dehydrogenase coupled to phenytoin or phenobarbital (tab. 1).

Tab. 1. Test procedure for the Emit phenobarbital and phenytoin assay with the Eppendorf analyzer 5010.

Serum

Reagent A (antibody/substrate/NAD ${ }^{+}{ }^{\mathbf{a}}$

$10 \mu 1$

Preincubation: 15 minutes at $25^{\circ} \mathrm{C}$

Reagent B (drug-enzyme conjugate) ${ }^{a}$

$100 \mu 1$

Wavelength: $334 \mathrm{~nm}$, program for aspartate amino-transferase, temperature $25^{\circ} \mathrm{C}$. First reading of absorbance 30 seconds and last reading 180 seconds after addition of reagent $B$.

a) Reagent $A$ is diluted $1: 13.5$ and reagent $B$ 1:2.5 with $55 \mathrm{mmol} / 1$ Tris-HCl buffer (pH 7.9).

The first reading of absorbance is performed 30 seconds and the last reading 180 seconds after the addition of reagent $B$ at a wavelength of $334 \mathrm{~nm}$. The program for aspartate aminotransferase of the Eppendorf analyzer is suited for this procedure. The absorbance differences $(\Delta A)$ obtained are used to calculate the results. From each absorbance reading $\Delta A$ the absorbance of the zero standard $\Delta \mathbf{A}_{\mathrm{O}}$ is subtracted. As these absorbance differences are greater than those obtained by the original method, they have to be divided by a constant factor before being plotted on the Emit graph paper (a modified logit function paper).

Calibrators and all samples were determined in duplicate. Precision and accuracy were checked within every run. Control sera from Syva and Biotrol Corporation have proved useful for this purpose.

\section{Results and Discussion}

\section{Standard curves}

Emit standard curves obtained by the Eppendorf analyzer 5010 are shown in figures 1 and 2. These calibration curves are in accordance with the manufacturer's assay

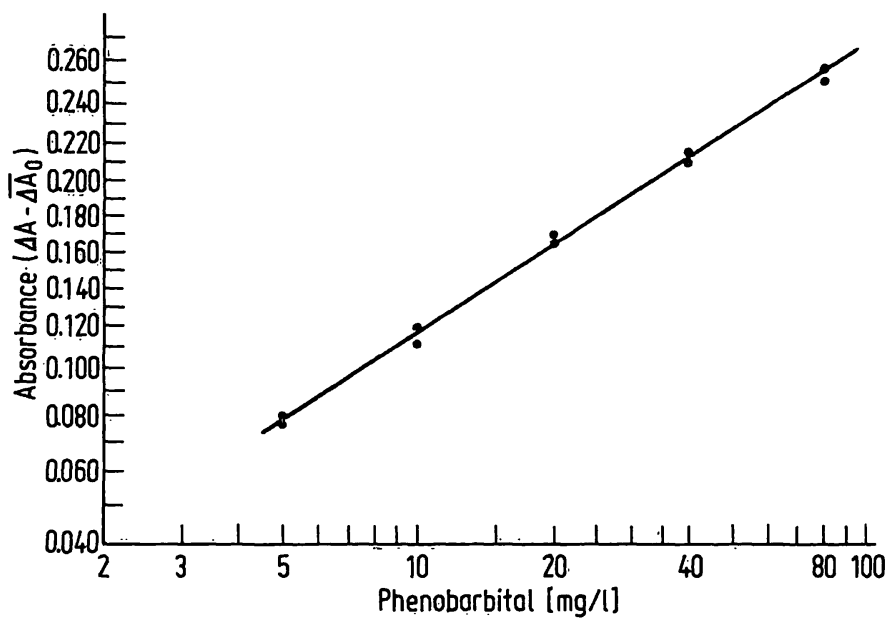

Fig. 1. Typical Emit standard curve for phenobarbital with the Eppendorf analyzer 5010.

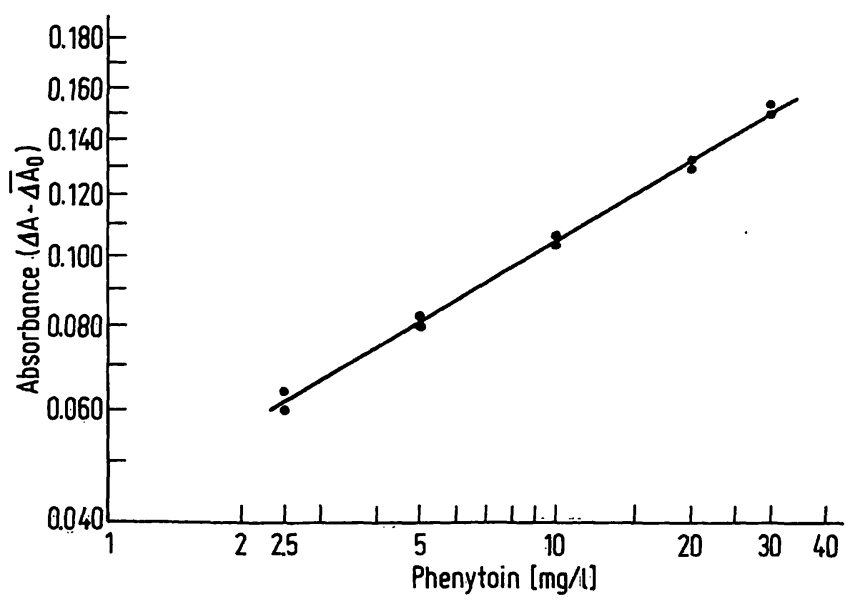

Fig. 2. Typical Emit standard curve for phenytoin with the Eppendorf analyzer 5010.

performance specifications for the original method. The range of linearity encompasses values from $2.5-30 \mathrm{mg} / 1$ $(9.9-118.9 \mu \mathrm{mol} / \mathrm{l})$ with the phenytoin assay and from $5-80 \mathrm{mg} / 1(21.5-344.5 \mu \mathrm{mol} / \mathrm{l})$ with the phenobarbital assay. Concentrations below $2.5 \mathrm{mg} / 1$ phenytoin and 5.0 $\mathrm{mg} / \mathrm{l}$ phenobarbital are regarded as being below the detec- 
tion limit. Samples with concentrations of phenytoin above $30 \mathrm{mg} / 1$ and phenobarbital above $80 \mathrm{mg} / \mathrm{l}$ have to be diluted with a $70 \mathrm{~g} / 1$ bovine albumin solution.

The change of absorbance during the 150 seconds reading time is shown for various phenobarbital concentrations in figure 3. Similar results were obtained by the Emit phenytoin assay. There is a non-linearity between 30 and 80 seconds, then the curve becomes almost linear. The 150 seconds reading time ensures an adequate absorption change, for sufficient sensitivity. The absorbance change produced by the blank is considerable. The difference between this blank value and the absorbance changes caused by the various calibrators is comparatively low. This ratio appears to be unfavorable with respect to the precision. The same disadvantages were observed with the original (9) and a modified procedure (7).

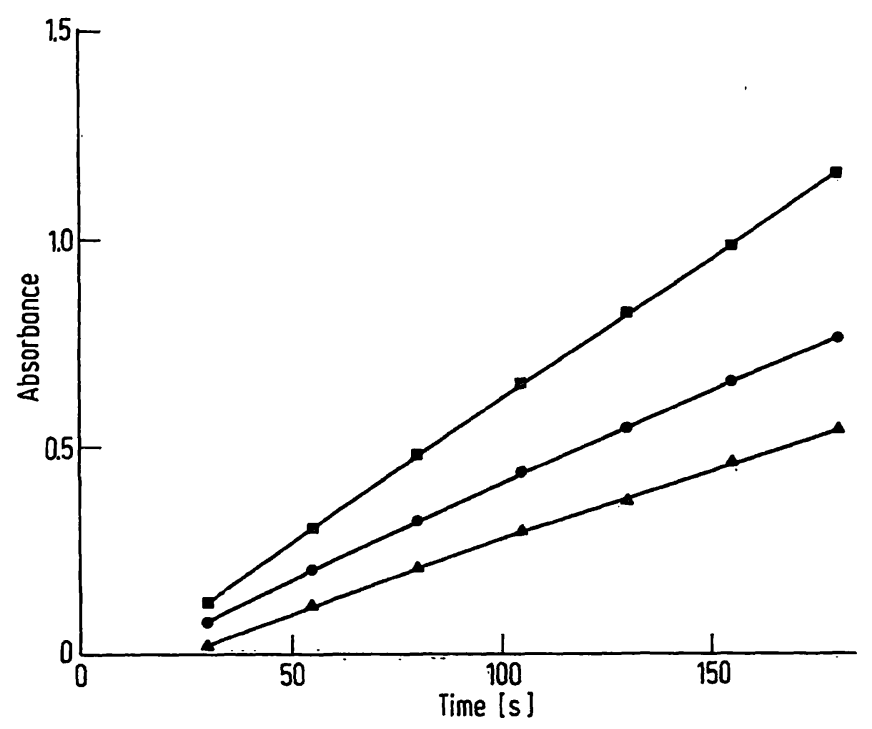

Fig. 3. The absorbance change of the Emit assay fọt various phenobarbital concentrations. Blank $\wedge-4,0,0 \mathrm{mg} / 1$ $\bullet-\longrightarrow$ and $80 \mathrm{mg} / \mathrm{l}$ - phenobarbital.

\section{Precision}

The precision of the Emit system for the quantitative determination of phenobarbital and phenytoin in serum at various concentrations of calibrators and commercial control sera is shown in table 2 . With most of the calibrators and control sera tested the coefficient of variation within series ranged from $6-13 \%$ and from day to day from $8-15 \%$. The precision within series of gas-liquid chromatography was determined by the repeated analysis $(n=10)$ of a spiked human serum containing phenobarbital $(20.0 \mathrm{mg} / \mathrm{l})$ and phenytoin $(20 \mathrm{mg} / \mathrm{l})$. The average phenobarbital cọncentration found was $20.0 \mathrm{mg} / \mathrm{l}$ with a coefficient of variation of $3.8 \%$. The average phenytoin concentration was $19.2 \mathrm{mg} / 1$ with a coefficient of variation of $4.7 \%$. From day to day variation was determined by analyzing
Tab. 2. The precision of the Emit system for the quantitative determination of phenobarbital and phenytoin in serum at various concentrations of calibrators and commercial control sera. Assays were performed in duplicates on 20 days $(n=40)$.

\begin{tabular}{|c|c|c|c|c|}
\hline \multirow{3}{*}{$\begin{array}{l}\text { Pheno- } \\
\text { barbital } \\
\text { or pheny- } \\
\text { toin con- } \\
\text { centra- } \\
\text { tion } \\
\text { (mg/l) }\end{array}$} & \multicolumn{2}{|c|}{$\begin{array}{l}\text { Precision of the pheno- } \\
\text { barbital assay }\end{array}$} & \multicolumn{2}{|c|}{$\begin{array}{l}\text { Precision of the phenytoin } \\
\text { assay }\end{array}$} \\
\hline & $\begin{array}{l}\text { From day } \\
\text { to day } \\
\bar{x}(C V)^{a}\end{array}$ & $\begin{array}{l}\text { Within } \\
\text { series } \\
\bar{x}(C V)\end{array}$ & $\begin{array}{l}\text { From day } \\
\text { to day } \\
\overline{\mathbf{x}} \text { (CV) }\end{array}$ & $\begin{array}{l}\text { Within } \\
\text { series } \\
\bar{x}(C V)\end{array}$ \\
\hline & $(\mathrm{mg} / \mathrm{l})(\%)$ & $(\mathrm{mg} / \mathrm{l})(\%)$ & $(\mathrm{mg} / \mathrm{l})(\%)$ & $(\mathrm{mg} / \mathrm{l})(\%)$ \\
\hline
\end{tabular}

Cali-

brators

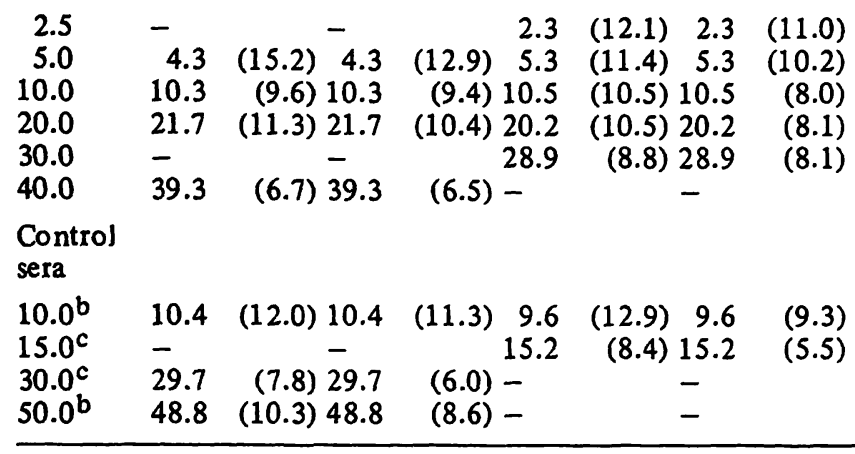

a) mean value with coefficient of variation in parenthesis; b) Biotrol-therapeutique (Laboratoires Biotrol); c) AED control (Syva).

the same spiked serum at 13 days. The average phenobarbital concentration was $20.0 \mathrm{mg} / \mathrm{l}$ with a coefficient of variation of $5.1 \%$ and the mean phenytoin concentration $19.8 \mathrm{mg} / \mathrm{l}$ with a coefficient of variation of $4.3 \%$. At a phenobarbital or phenytoin concentration of $20.0 \mathrm{mg} / 1$ the precision of the Emit system was lower than that of gas-liquid chromatography.

\section{Accuracy}

The results for the recovery of phenobarbital and phenytoin by the Emit system are shown in table 3. Both compounds were added to pooled drug-free human serum. The recovery at various concentrations between 10 and $50 \mathrm{mg} / \mathrm{l}$ was adequate: $93-99 \%$ for phenobarbital and $93-101 \%$ for phenytoin.

Tab. 3. The recovery of phenobarbital and phenytoin by the Emit system in spiked serum samples. Determinations were performed in duplicates on five days $(n=10)$.

\begin{tabular}{lcc}
$\begin{array}{l}\text { Drug concentration } \\
\text { Weighed in } \\
\text { (mg/l) }\end{array}$ & $\begin{array}{l}\text { Found } \\
(\mathrm{mg} / \mathrm{l})\end{array}$ & $\begin{array}{l}\text { Recovery } \\
(\%)\end{array}$ \\
\hline 1. Phenobarbital & & \\
10 & 9.3 & 93 \\
25 & 24.7 & 99 \\
50 & 47.3 & 95 \\
2. Phenytoin & & \\
10 & 10.1 & 101 \\
20 & 18.5 & 93 \\
30 & 29.0 & 97 \\
\hline
\end{tabular}


In order to study the linearity of the Emit system, sera from patients with high concentrations of phenobarbital and phenytoin were diluted with a $70 \mathrm{~g} / 1$ albumin solution. The results shown in table 4 indicate a satisfactory linearity in the range tested.

Tab. 4. The linearity of the Emit phenobarbital and phenytoin assay. Samples from patients containing the indicated drugs were diluted with a $70 \mathrm{~g} / \mathrm{l}$ albumin solution.

\begin{tabular}{llrrrl}
\hline Drug & $\begin{array}{l}\text { Dilution } \\
\text { of } \\
\text { sample }\end{array}$ & $\begin{array}{l}\text { Concentration (mg/1) } \\
\text { Found }\end{array}$ & $\begin{array}{r}\text { Difference } \\
\text { Expected Differ- } \\
\text { ence }\end{array}$ \\
\hline Pheno- & none & 47.5 & & & \\
barbital & $1: 2$ & 25.1 & 23.8 & +1.3 & +5.5 \\
& $1: 4$ & 13.4 & 11.9 & +1.5 & +12.6 \\
& $1: 6$ & 7.6 & 7.9 & -0.3 & -3.8 \\
& $1: 10$ & 5.2 & 4.8 & +0.4 & +8.3 \\
Phenytoin & none & 29.0 & & & \\
& $1: 2$ & 13.4 & 14.5 & -1.1 & -7.6 \\
& $1: 4$ & 6.6 & 7.3 & -0.7 & -9.6 \\
& $1: 6$ & 4.4 & 4.8 & -0.4 & -8.3 \\
& $1: 10$ & 2.6 & 2.9 & -0.3 & -10.3 \\
\hline
\end{tabular}

Furthermore phenobarbital and phenytoin levels were determined by gas-liquid chromatography and Emit in sera from patients on a medication of primidone $(n=57)$ and phenytoin $(n=43)$.

For the measurement of phenobarbital, the leastsquares regression analysis of 57 specimens (fig. 4) showed the slope of the line to be 0.95 . The value of the intercept was $1.39 \mathrm{mg} / \mathrm{l}$. Random error was estimated at $11.5 \mathrm{mg} / \mathrm{l}$ from the standard error (10). The correlation between the results was high $(r=0.968)$. For a gas-liquid chromatographic value of $30 \mathrm{mg} / \mathrm{l}$, the Emit procedure would give an average value of 29.9 $\mathrm{mg} / \mathrm{l}$ (standard error $\mathrm{S}_{\mathrm{y}}=11.5 \mathrm{mg} / \mathrm{l}$ ).

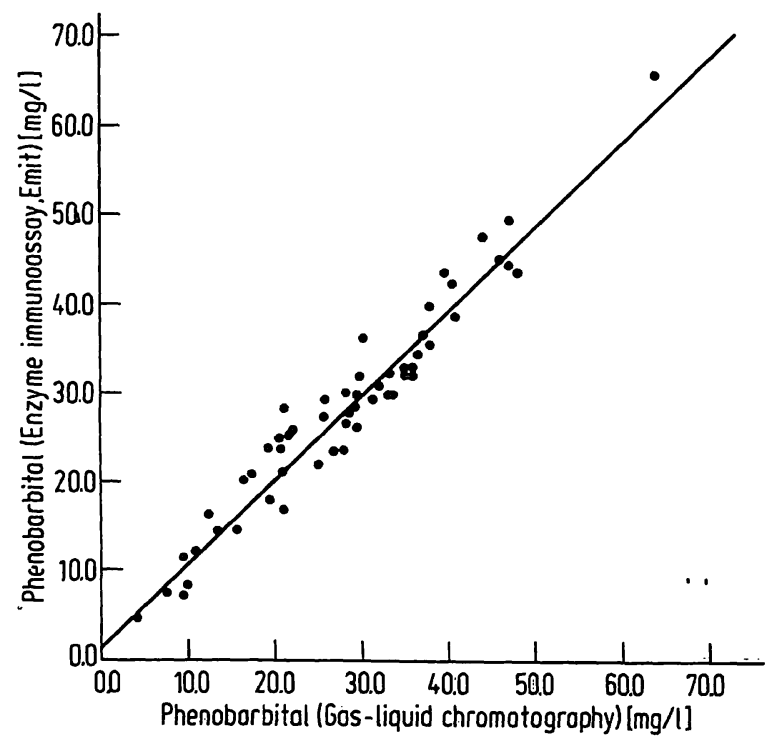

Fig. 4. Serum phenobarbital concentrations as measured by Emit and gas-liquid chromatography $(n=57)$. Slope: 0.95 , intercept: $1.39 \mathrm{mg} / \mathrm{l}$ correlation coefficient: 0.968 .
For the determination of phenytoin the values of slope and intercept were, respectively, 0.93 and $1.16 \mathrm{mg} / 1$ (fig. 5). The results obtained with both methods corre: lated well (coefficient of correlation $\mathrm{r}=0.978$ ). For a gas-liquid chromatographic value of $15.0 \mathrm{mg} / 1$ the Emit phenytoin assay would give an average value of 15.1 $\mathrm{mg} / \mathrm{l}$ (standard error $\mathrm{S}_{\mathbf{y}}=7.3 \mathrm{mg} / 1$ ).

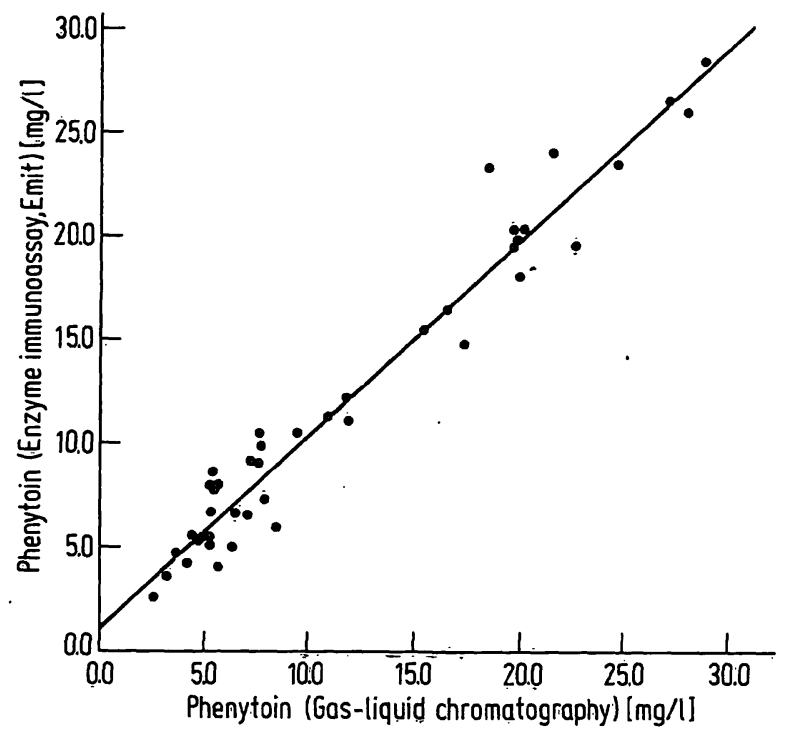

Fig. 5. Serum phenytoin concentrations as measured by Emit and gas-liquid chromatography $(n=43)$. Slope: 0.93 , intercept: $1.16 \mathrm{mg} / \mathrm{l}$, correlation coefficient: 0,978 .

Both Emit assays appeared to correlate sufficiently with gas-liquid chromatography. The use of the Emit results would not change the clinical interpretation. Similar results have been reported for the Emit technique performed on Gilford or Beckman instruments $(9,11-13)$ and on the Rotochem II (7).

\section{Specificity}

The specificity of the Emit assays was tested by the determination of the cross-reactivity with structurally related compounds and other antiepileptic drugs. The results obtained with spiked human serum samples are shown in table 5. For each drug the concentration was determined at which it exerts an absorbance equivalent to $5 \mathrm{mg} / \mathrm{l}$ phenobarbital or phenytoin in the corresponding Ėmit assay. The Emit phenytoin assay seemed to be very specific. In addition to the phenytoin metabolite, 5-(p-hydroxyphenyl)5-phenylhydantoin, only mephenytoin slightly cross reacted in this assay. It should be noted that phenytoin-3-norvaline is apparently completely metabolized in vivo so that serum levels cannot be determined. With serum samples from patients $(n=20)$ receiving various drugs other than phenytoin no positive results were observed.

The Emit phenobarbital assay was less specific. Methylphenobarbital, cyclobarbital, cyclopal, and amobarbital showed a cross-reaction. Serum samples from patients 
Tab. 5. Cross-reactivity of drugs in serum ${ }^{\mathrm{a}}$ with the Emit phenobarbital and phenytoin assay.

Emit phenobarbital assay

\begin{tabular}{lc}
\hline Compound (trade name) & $\mathrm{mg} / \mathrm{l}^{\mathrm{b}}$ \\
Phenobarbital (Luminal) & 5 \\
Methylphenobarbital (Prominal) & 7 \\
Cyclohexyl-2-methylaminopropanphenobarbital (Maliasin) & 7 \\
Cyclobarbital calcium (Phanodorm) & 40 \\
Cyclopal & 320 \\
Amobarbital (Amytal) & 640 \\
Secobarbital (Seconal) & $\mathrm{NR}$ \\
Pentobarbital (Neodorm) & $\mathrm{NR}$ \\
Hexobarbital (Evipan) & $\mathrm{NR}$ \\
Heptabarbital (Medomin) & $\mathrm{NR}$ \\
Barbital (Veronal) & $\mathrm{NR}$ \\
Primidone (Mylepsin) & $\mathrm{NR}$ \\
2-Ethyl-2-phenylmalondiamide & $\mathrm{NR}$ \\
Bemegride (Eukraton) & $\mathrm{NR}$ \\
Phenytoin (Zentropil) & $\mathrm{NR}$ \\
5-(p-Hydroxyphenyl)-5-phenylhydantoin & $\mathrm{NR}$ \\
Propylvalerianate sodium (Ergenyl) & $\mathrm{NR}$ \\
Clonazepam (Rivotril) & $\mathrm{NR}$ \\
Chlordiazepoxide (Librium) & $\mathrm{NR}$ \\
Diazepam (Valium) & $\mathrm{NR}$ \\
Chlorpromazine (Megaphen) & $\mathrm{NR}$ \\
Carbamazepine (Tegretal) & $\mathrm{NR}$ \\
Sulthiame (Ospolot) & $\mathrm{NR}$ \\
Ethosuximide (Petnidan) & $\mathrm{NR}$ \\
Mesuximide (Petinutin) & $\mathrm{NR}$ \\
Paramethadione (Paradione) & $\mathrm{NR}$ \\
Trimethadione (Tridione) & $\mathrm{NR}$ \\
Glutethimide (Doriden) & $\mathrm{NR}$ \\
& \\
\hline
\end{tabular}

Emit phenytoin assay

Compound (trade name) $\mathrm{mg} / \mathbf{l}^{\mathrm{b}}$

Phenyto in (Zentropil)

5-(p-Hydroxyphenyl)-5-phenylhydantoin

Mephenyto in (Mesantoin)

Methylstyrildibromhydantoin (Anirrit)

Phenobarbital (Luminal)

Methylphenobarbital (Prominal)

Cyclohexyl-2-methylaminopropan-phenobarbital (Maliasin)

Primidone (Mylepsin)

2-Ethyl-2-phenylmalondiamide

Ethosuximide (Petnidan)

Mesuximide (Petinutin)

Propylvalerianate sodium (Ergenyl)

Clonazepam (Rivotril)

Chlordiazepoxide (Librium)

Diazepam (Valium)

Chlorpromazine (Megaphen)

Carbamazepine (Tegretal)

Sulthiame (Ospolot)

Paramethadione (Paradione)

Trimethadione (Tridione)

5
50
480
$N R$
$N R$
$N R$

$N R$
$N R$
$N R$
$N R$
$N R$
$N R$
$N R$
$N R$
$N R$
$N R$
$N R$
$N R$
$N R$
$N R$
$N R$
$N R$

a) drugs were added to normal human serum; b) concentrations exerting an absorbance equivalent to $5.0 \mathrm{mg} / \mathrm{l}$ phenobarbital or phenytoin; c) no reaction up to concentrations of $1000 \mathrm{mg} / \mathrm{l}$.

receiving drugs such as primidone and methylphenobarbital, which are converted to phenobarbital, yielded positive results. Phenobarbital levels are very often used for monitoring primidone therapy as they fluctuate less than primidone levels. With serum samples from patients $(n=20)$ not taking any of the drugs mentioned above but receiving phenytoin and/or other drugs no false positive results were obtained.

\section{Interferences}

Bilirubin concentrations up to $300 \mu \mathrm{mol} / 1$ did not affect the results of both assays. Extremely lipemic and hemolytic sera could not be analyzed by this method. Hemoglobin concentrations up to $2.0 \mathrm{~g} / 1$ showed no interference. With the determination of phenobarbital by gas-liquid chromatography a slight interference of phenylethylmalondiamide, a metabolite of primidone, was observed, owing to an incomplete separation of the two substances.

\section{Clinical experience}

The measurement of phenytoin and phenobarbital appears to be of great clinical value. In many cases irregular drug intake and inadequate dosage could be objectified and the diagnosis of an intoxication confirmed. To illustrate the clinical relevance of the determination of antiepileptic drug levels an example from our pediatric clinic is given in figure 6. A twelve year old girl treated with phenytoin and primidone, was sent to our pediatric clinic because of toxic symptoms such as nystagmus and ataxia, which increased during the following days. The clinical signs pointed to an intoxication by phenytoin.

This diagnosis was confirmed by the determination of the serum levels of phenobarbital and phenytoin. The serum levels of phenytoin were far above the therapeutic range, whereas the phenobarbital concentrations only slightly exceeded the recommended values. After the phenytoin medication was discontinued the phenytoin level decreased and the toxic symptoms disappeared.

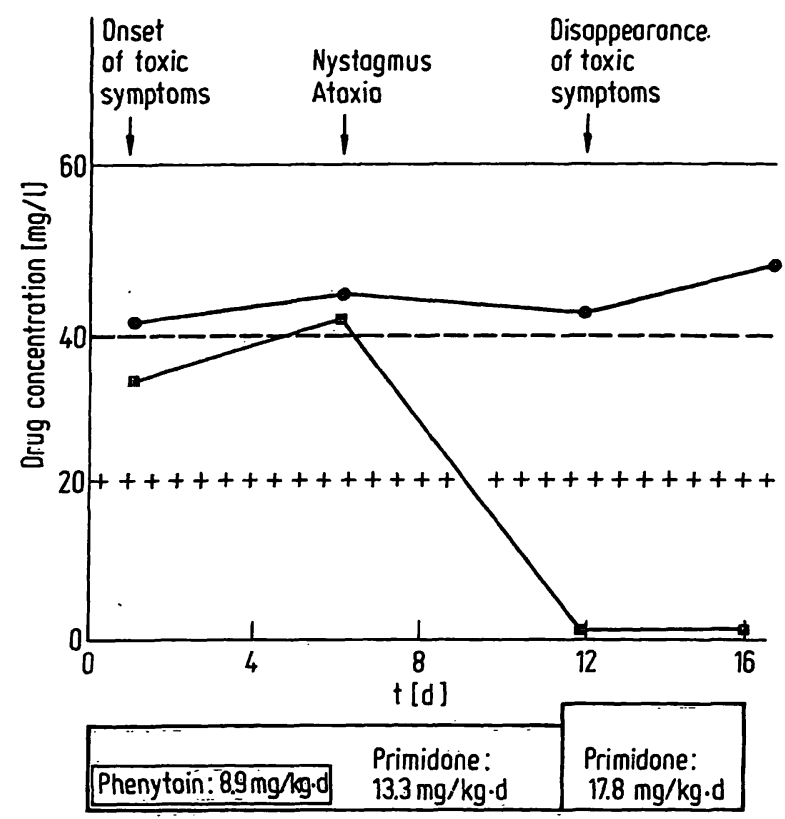

Fig. 6. Comparison of clinical signs and serum drug levels in a patient intoxicated by phenytoin.

Phenobarbital level: •-๑, phenyto in level: - Borderline of toxic level with phenobarbital $(40 \mathrm{mg} / \mathrm{l})$ - - and with phenytoin $(20 \mathrm{mg} / \mathrm{l})++$. 


\section{Conclusion}

According to our experience the Emit assays permit rapid and reliable determinations of phenobarbital and phenytoin in serum.

The results of the enzyme immunoassays for phenytoin and phenobarbital correlated well with those obtained by gas-liquid chromatography. No clinically significant difference was found, so that the Emit results would not change the clinical interpretation.

Compared with gas-liquid chromatography the Emit technique has the following advantages: the tests require a sample volume of only $10 \mu \mathrm{l}$ serum per determination and can easily be mechanized. One technician is able to analyze 30 unknown samples (duplicate determinations) by an Eppendorf analyzer 5010 within 90 minutes. This time however can be reduced to about 60 minutes, if the Eppendorf analyzer is connected on-line to an electronic data processing system (Porth, A. \& Oellerich, $M$., in preparation).

\section{References}

1. Kutt, H. \& Penry, J. K. (1974), Arch. Neurol. 31, 283-288.

2. Lund, L. (1974), Arch. Neurol 31, 289-294.

3. Rubenstein, K. E., Schneider, R. S. \& Ullman, E. F. (1972), Biochem. Biophys. Res. Comm. 47, 846-851.

4. Oellerich, M., Külpmann, W. R. \& Haeckel, R. (1977), J. Clin. Chem. Clin. Biochem. 15, 000-000.

5. Mule, S. J., Bastos, M. L. \& Jukofsky, D. (1974), Clin. Chem. 20, 243-248.

6. Broughton, A. \& Ross, D. L. (1975), Clin. Chem. 21, 186 -189 .

7. Finley, P. R., Williams, R. J. \& Byers, J. M. (1976), Clin. Chem. 22, 911-914.

8. Fiereck, E. A. \& Tietz, N. W. (1971), Clin. Chem. 17, 1024-1027.
Unfortunately the costs for the Emit reagents are rather high. If $\mathbf{3 0}$ samples were analyzed the price including reagents, pertinent supplies, standards and technician time was about 5 US\$ per Emit test. Single determinations are much more expensive (tab. 6).

Tab. 6. Costs of a quantitative determination of phenobarbital or phenytoin by Emit adapted to the Eppendorf analyzer 5010.

\begin{tabular}{lllll}
\hline Costs & $\mathrm{n}^{\mathrm{a}}=1$ & $\mathrm{n}=10$ & $\mathrm{n}=20$ & $\mathrm{n}=30$ \\
\hline $\begin{array}{l}\text { Technician } \\
\text { time }\end{array}$ & US $\$ 4.81$ & 0.73 & 0.47 & 0.37 \\
$\begin{array}{l}\text { Reagents and } \\
\text { pertinent supplies }\end{array}$ & US $\$ 33.59$ & 6.55 & 4.95 & 4.42 \\
$\begin{array}{l}\text { Standards } \\
\text { Total }\end{array}$ & US $\$ 7.21$ & 0.74 & 0.37 & 0.24 \\
\hline
\end{tabular}

a) $n=$ number of specimens per series; b) costs per minute technician time: 0.11 US $\$$.

9. Legaz, M. \& Raisys, V. A. (1976), Clin. Biochem. 9, 35-38.

10. Westgard, J. O. \& Hunt, M. R. (1973), Clin. Chem. 19, 49-57.

11. Pippenger, CH. E., Bastiani, R. J. \& Schneider, R. S. in Clinical Pharmacology of Antiepileptic Drugs (H. Schneider, D. Janz editors), Berlin, Springer (1975), 331-335.

12. Spiehler, U., Sun, L., Miyadạ, D. S., Sarandis, S. G., Walwick, E. K., Klein, M. W., Jordan, D. B. \& Jessen, B. (1976), Clin. Chem. 22, 749-753.

13. Booker, H. E. \& Darcey, B. A. (1975), Clin. Chem. 21, 1766-1768.
Dr. M. Oellerich Institut für Klinische Chemie Karl-Wiechert-Allee 9 D-3000 Hannover 61 